\title{
A Jacobean's Source Revisited: George Chapman and Alessandro Piccolomini's Alessandro.
}

Rita Belladonna

The aim of the present paper is to re-examine Alessandro Piccolomini's Alessandro in order to identify some significant elements in it and to ascertain the extent to which they relate to George Chapman's May-Day.

Let us briefly look at the plots of both plays. Alessandro, written in 1544 , to be performed during the Carnival of that year, ${ }^{1}$ consists of three contrapuntally related plots, none of which quite emerges in importance above the others. In the most romantic of the three stories, the two protagonists, Aloisio and Lucrezia, have been accidentally separated because of the political turmoils in their native Sicily. When they happen to meet again in Pisa, they are disguised respectively as a girl, Lampridia, and as a boy, Fortunio. Fortunio, that is Lucrezia, falls in love with Lampridia who, not unnaturally, reminds her of Aloisio. The final agnition solves every problem, and the two lovers can eventually get married. The second plot equally contains some romantic elements, tempered by its more bourgeois tone. Cornelio, a promising young man, falls in love with Lucilla, a virtuous girl. He gradually loses all interest in his studies and his mind becomes totally obsessed by love. With the help of his servant, Querciuola, Cornelio succeeds in obtaining a meeting with Lucilla. Her initially negative attitude toward him has now changed, and she has written him a letter to explain that her apparent hardness was only meant to test him. During their meeting, Cornelio persuades Lucilla to allow him to climb up to her window and into her bedroom. However, his efforts to endanger her chastity prove fruitless and, struck by her purity, he decides that he wants to marry her. Romantic love, therefore, triumphs over Cornelio's own lustful feelings, and also over the discouraging scepticism of Alessandro, an older friend who accompanies him to the meeting. In sharp opposition to these 
romantic stories, the third plot deals with the senile infatuation inspired in Gostanzo, Lucilla's doting old father, by Brigida, the wife of a bragging captain. Querciuola, Cornelio's witty servant, convinces Gostanzo to dress up as a locksmith in order to gain access to Brigida unnoticed. This is a trick arranged to keep him away from home while Cornelio is talking to Lucilla. The foolish old man falls into the trap and is locked up in Brigida's house, where a little later he is discovered, though not recognized, by the angry Captain Malagigi. Eventually Brigida succeeds in fooling her husband into thinking that the man he found in the house was probably a burglar.

When Chapman remade Alessandro into a new play around 1601 or $1602,{ }^{2}$ he eliminated the first plot almost entirely. Lucrezia becomes Theagine who, under the name of Lionell, serves Leonoro as a page. Yet, it is Leonoro, not the disguised Theagine, who falls in love with Lucretio, now disguised as Lucretia. Eventually, however, it is another character, Lodovico, which is introduced into Lucretia's chamber and accidentally discovers the supposed girl's real sex. His discovery results in a well-known coup de théâtre, which is among the best in the English comedy of the time. Agnition occurs during the final masque, in which Theagine's disguise is significantly used to reveal her identity rather than to conceal it. Being a girl dressed up as a boy, she is now asked to disguise herself as a girl (which is what she actually is) in order to play a joke on a gull called Innocentio. The second plot preserves the bourgeois tone of the original. Aurelio, a romantic young man, loves Aemilia, who is engaged to marry a greedy foolish old man called Gasparo. Lodovico, Aurelio's friend, persuades Aemilia to defy social convention and to grant Aurelio a meeting. The lovers decide to keep their feeling a secret until Aemilia can obtain her father's consent. Eventually Lorenzo, the girl's father, consents to their marriage, since Gasparo has proved to be a very cold suitor. Lorenzo is the main character in the third plot, which closely resembles its counterpart in Alessandro, except for the fact that Franceschina's husband, Quintiliano, is not just a braggart but also a genial trickster. Prompted by Angelo, who is Aurelio's servant, Lorenzo dresses up as a chimney-sweeper and is locked up in Quintiliano's house.

It will be obvious by now that Alessandro presents a mixture of romantic and satirical elements. There is a noticeable gradation in the three closely interwoven plots which constitute the play. The story about Fortunio and Lampridia, with the two protagonists' momentary loss of sexual identity and its consequent emotional ambiguity, the girl's strife for survival and its strong narrative 
element, clearly belongs to the romance tradition. The plot involving Cornelio and Lucilla deals with love triumphing over lust. ${ }^{3}$ Cornelio's feelings toward Lucilla deepen as the play progresses, up to the final cathartic effect leading to conjugal love. Yet, Cornelio and Lucilla are immersed in contemporary Sienese reality, whereas Aloisio and Lucrezia emerge out of the nowhere of romance, labelled as Sicily in this play. The romantic element is at its lowest ebb in the farcical plot relating to Gostanzo, the foolish old man led astray by senile infatuation to the point of becoming a dupe. In order to account for the presence of the satirical elements in Piccolomini's play, we must consider the influence exercised upon him by Pietro Aretino. Piccolomini met Aretino around 1538 in Padua. ${ }^{4}$ Even before then, he must have been an attentive reader of Aretino's works, as shown by his celebrated dialogue, written shortly before his departure for Padua, which bears the ironic title $A$ Dialogue about the best Behaviour for Women (Dialogo della bella creanza delle donne). In it Raffaella, a bawd clearly related to Alvigia in Aretino's La Cortigiana, persuades a young wife to accept the attentions of a lover. The character in Alessandro in which Aretino's influence is most evident is no doubt Niccoletta, another witty bawd, whose allusions to Sienese characters and places, together with her racy language, transform her from a stock comedy type into a sharply-defined character deeply rooted in middle-class Siena. Again, Aretino's satirical attitude toward the Church of Rome must have been largely responsible for the numerous sarcastic remarks about the corruption of the mendicant orders to be found in Alessandro. These critiques are typical of the negative attitude toward the Church which had developed in Italy in the years preceding the opening of the Council of Trent. Piccolomini's powers of psychological observation, ascribed by Benedetto Croce to his philosophic training, ${ }^{5}$ enabled him to create satirical types subtler and better focused than those of traditional comedy. Nowhere does this appear more clearly than in the servants in Alessandro. Each of them uses his wits to trick his master in a different way: Querciuola by persuading Gostanzo to dress up as a locksmith in order to meet Brigida, who also happens to be Querciuola's mistress; Fagiuolo by ostensibly believing all the tall stories told by Captain Malagigi, his bragging master; and Ruzza by pretending not to recognize Gostanzo when the latter returns home disguised as a locksmith and chased by the angry Captain. A satirical insight into these low-class characters occurs in Act II, scene 2, when the three meet and hold a mock debate, evidently a parody of the quesiti d'amore held by their social betters, about the question whether a woman is better than a good dinner or the opposite. The debate ends with Fagiuolo's statement that he 
prefers a good dinner followed by a woman as a dessert. Two more servants for whom there is no precedent in classical comedy may owe some inspiration to Giannicco in Aretino's Il Marescalco. These are the two young errand boys, Furbetto and Brachetto, portrayed by Piccolomini with delightful humour as half childish, half corruptly sly. Then, there are altogether five completely different servant types in Alessandro. They are observed with ironic humour and detachment by Piccolomini, a member of a prominent family, who belongs on the side of the ruling class. Though, in accordance with Aristotelian theory, Piccolomini believed that lowly characters are the most important ones in comedy, we also find remarkable individual features in some of the other characters as well. Lucilla has a much better defined personality than the mostly semianonymous girls in traditional comedy. We have seen that she puts Cornelio's love to the test, and she even comes to the window for their interview with a rope-ladder in her pocket, which she only intends to use as she sees fit. Lucrezia, the girl disguised as a boy, a figure frequent in romances and short stories, is pervaded by a romantic yearning for Aloisio. That, together with the momentary loss of sexual identity symbolized by her disguise, result in her passion for Lampridia, which thus becomes a vehicle for dramatic irony. Cornelio succeeds in overcoming his own sensuality when faced with Lucilla's chaste disposition, a fact which differentiates him from the somewhat vapid young men of traditional comedy.

Chapman must have found the bourgeois satire in Alessandro quite congenial. He must also have realized that Piccolomini had gone a long way toward delineating characters surpassing the stock types of comedy in their individuality. The Italian play provided an excellent background against which characters could be developed into humours, according to Ben Jonson's example. Thus, whereas he almost eliminated the most romantic plot, as we have seen, Chapman gave greater relief to satire viewed from a Jonsonian angle. Malagigi becomes Quintiliano in May-Day, more of a trickster than a braggart, inspired by Jonson as well as by Shakespeare's Falstaff. ${ }^{6}$ Of his two gulls one, Giovenelle, has just returned from Padua University and he serves to satirize the helplessness of culture in front of a master trickster. Gasparo, Aemilia's suitor, is totally dominated by his greed for her money. Querciuola, Cornelio's intriguing servant in Alessandro, is split into two characters: Angelo, Aurelio's servant, and Lodovico, Lorenzo's nephew and a gentleman, who, led by his contempt for his foolish uncle, joins in the intrigue against him in order to help Aurelio to marry Aemilia. A rather important point is noticeable: Chapman has eliminated all the servants from his play, except 
Angelo, and he has transferred their tricks and spirit of intrigue to the upper classes, thus introducing a profound change into the traditional separation existing in comedy between intriguing servants and helpless masters. This enables Chapman to view middleand upper-class society through a more realistic lens. Quintiliano's trickery places this miles gloriosus in a category very close to that of Jonson's rogues. Lodovico, on the other hand, is in open revolt against the hypocrisy of social conventions which would require Aemilia to marry a greedy old fool like Gasparo. Without completely crossing the Jonsonian anti-romantic Rubicon, Chapman uses his characters in order to construct a more serious contemporary social satire than Piccolomini. The latter makes fun of characters which, because of the author's skill in reproducing popular speech, are deeply rooted in the milieu of Siena, a moribund republic whose gradual decline, caused by internal factions and the consolidation of the Medici, was gathering ever greater momentum when the play was written. Chapman, on the other hand, attacks the hypocrisy of a society which he perceives to be only apparently flourishing, and in which money has become the sole determining factor, both as an incentive to trickery and as a means for fast climbers to reach the top of the social ladder. Hence the numerous allusions to money in the course of the play, from Gasparo's eagerness to obtain Aemilia's dowry to Quintiliano's interested advice to Innocentio, a gull, about how to dispose of the latter's property in order to obtain ready cash. ${ }^{7}$ Chapman also eliminated the title character, Alessandro, which in the Italian play probably represents the author himself, a mature observer of the action, an idiotes 8 full of sceptical experience about love in contrast to Cornelio's youthful passion for Lucilla. Alessandro voices his mistrust of women in a play to a great extent written for their glorification and, paradoxically, he proves to be wrong about Lucilla in the end. In May-Day, on the other hand, the idealization of women is completely gone. Instead, there is bitter critique, mainly expressed by Lodovico. ${ }^{9}$

Our examination of both plays has so far led us to identify what appears to be an unusual situation: contrary to expectation, the Italian play is in fact considerably more romantic in its general tone and in its attitude to women than the English one. In order partly to account for this rather surprising result, we must consider the public for which the plays were written. Alessandro, no less than May-Day, was written for a coterie, the Accademia degli Intronati of Siena. It is beyond our scope to define the aims of that learned philosophic and literary academy. ${ }^{10}$ However, there is one point which needs to be emphasized in the present context, that of 
the presence among the Intronati of numerous ladies from noble Sienese families. There is no doubt that was a major factor in determining the general tone and contents of the plays written by the Academy members. It was customary for ladies from prominent families to be invited by the Intronati to attend some of their activities. There was an obvious link between the major purpose of the academy, the advancement of the vernacular language as opposed to Latin and Greek, and the participation of women, most of whom formed part of a large social group to whom culture was only accessible in Italian.11 The presence of such ladies among the public and the general feeling of deference and courtly homage toward them rendered it necessary for the Intronati to ascribe greater importance to the female characters than was usual in erudite comedy. Hence the use they made of adventurous stories often necessitating disguises, with the final triumph of love, which had to be pure and noble, often conjugal, as in Piccolomini's other play, L'Amor Costante. ${ }^{12}$ It is interesting to remark that Alessandro, as explained by the author in the first of his two prologues, was meant to convey a veiled warning to the Sienese ladies not to consort with ill-mannered lovers and not to indulge in vulgar entertainment. However, together with this tendency to stress the importance of idealistic love stories and the role of female characters, the opposite tendency to criticize women often insinuated itself in some of these plays, in a way remindful of Castiglione's Libro del Cortegiano. Alessandro shows this dichotomy. Two of the plots are romantic in tone, one of them relating more closely to middle-class realism. Yet, the third plot has an unfaithful wife as its heroine. Extremes meet: Lucrezia, the chaste heroine of the plot about the parted lovers, often appears on the stage with Niccoletta, the realistic bawd who voices the call to sensual pleasure. However, pure love triumphs in the end. Cornelio is symbolical of the refining effects of true love, a traditional theme bound to be of interest to a feminine audience. Also Chapman had to satisfy the demands of a limited public, but in a totally different sense. Having to please the fastidious taste of spectators like those at Blackfriars, who would seek relief in the private theatres from the romantic popular plays shown at the public theatres, ${ }^{13}$ Chapman naturally tended to veer toward satire, all the more so because of Ben Jonson's omnipresent influence. On the whole, the characters in May-Day are more important than any romantic complications in the plot. That is probably why the plot relating to the Sicilian lovers has almost totally disappeared, not because of its immorality, as has been suggested, but because it was too tearfully romantic to please Chapman's audience. Love 
tends to be viewed from a more satirical realistic angle in May-Day. Aemilia and Aurelio's story acquires a sharper edge of contemporary satire by the introduction of Gasparo, the disgusting old suitor. ${ }^{14}$ Aemilia lacks Lucilla's liveliness and independence. She has to be encouraged to rebel against her father's will by Lodovico, who expresses a strong critique of contemporary social conventions, particularly as they relate to women's behaviour. Just like Jonson, Chapman appears not to hold his female characters in any great esteem. Numerous slurs against women appear throughout the play, a proof, if any were required, that the element of courtly homage has vanished. Even disguise, that time-honoured device, is turned upside down, as we have seen, and used to reveal rather than to conceal identity.

It has been observed by Northrop Frye that literature faces inward into itself and outward as a structure with a social function. ${ }^{15}$ Alessandro faces more inward than outward into the cherished beliefs about pure love of the author himself and of the elite for whom the play was written, with satire as a spice which does not destroy the basic belief in romance. Chapman, prompted by Jonson, took the same play and turned it outward, compelling it to mirror the society which surrounded him. The final masque is thus symbolical of the psychological disguises of a society in which Quintiliano's trickery and inner weakness are never exposed. Thus Chapman's play, crowded as it is with characters far more important than the precarious plots, ultimately embodies a deeper critique of society than Piccolomini's. Both plays succeed in different ways in renewing the patterns of traditional comedy by means of personal and social elements.

The University of Western Ontario

\section{NOTES}

1 V. F. Cerreta (ed.), L'Alessandro (Siena, 1966).

2 V. T. Parrot (ed.), The Plays of George Chapman. The Comedies, vol. 2 (New York, 1961).

3 N. Frye, A Natural Perspective. The Development of Shakespearean Comedy and Romance (New York, 1965), p. 86: "Love conquers all, in general; it also conquers certain enemies of its own in particular. Of these, one of the most important is lust."

4 F. Cerreta, Alessandro Piccolomini letterato e filosofo senese del Cinquecento (Siena, 1960), pp. 42-44; R. Scrivano, Cultura e letteratura nel Cinquecento (Rome, 1966), particularly pp. $22-23$.

5 B. Croce, "Intorno alla commedia italiana del Rinascimento," La Critica, (1930), 21-24. Croce defines Piccolomini as an "Aretino gentil uomo."

6 M. MacLure, George Chapman. A critical Study (Toronto, 1966), p. 94: "[Quintiliano] ... who is modelled on Jonson's Tucca ... and sounds sometimes also like Falstaff played on a cracked recorder." 
7 V. A. D'Addario, Il problema senese nella storia italiana della prima metà del Cinquecento (Florence, 1958); L.C. Knights, Drama and Society in the Age of Jonson (New York, 1968), pp. 125-26, remarks on marriage as a form of fortunehunting and states that Chapman and Fletcher were pleading for a more civilized relation between the sexes.

8 N. Frye, pp. 92-93: ". . . in any well-constructed comedy there ought to be a character or two who remain isolated from the action, spectators of it, and identifiable with the spectator aspect of ourselves.... The idiotes is usually isolated from the action by being the focus of the anticomic mood, and so may be the technical villain ... or the butt ... or simply opposed by temperament to festivity ...." The latter description appears to suit Alessandro quite well.

9 J. Jacquot, George Chapman (1559-1634). Sa vie, sa poésie, son théâtre, sa pensée (Paris, 1951), p. 267: "Dans la mesure où notre poète hait la vie, il hait aussi la femme."

10 V. F. Cerreta, Alessandro Piccolomini cit., passim.

11 C. Dionisotti, Geografia e storia della letteratura italiana (Turin, 1967), p. $190 \mathrm{ff}$.

12 V. N. Borsellino, Rozzi e Intronati. Esperienze e forme di teatro dal "Decameron" al "Candelaio" (Rome, 1974), p. 76 ff. for some interesting remarks on the Sienese drama of the time.

13 A. Harbage, Shakespeare and the Rival Traditions (New York, 1952), passim.

14 Y. Parrot, op. cit., p. 736: "He [Chapman] eliminated the most offensive situations. ..." Also Lucilla has a rich, though unimportant, suitor, who eventually decides to become a bishop.

15 The observation was made by Professor Frye in the course of a lecture in the Tamblyn series, entitled The Reversal of Action, delivered at the University of Western Ontario on March 25, 1981. 